\title{
ARTICLES
}

\section{A REVIEW ON NEW GENERATION DISEASE: FIFTH DISEASE}

\author{
Dr. Justin Jeya Amutha*| Dr. Lordlin** \\ * Associate Professor, Smt. Nagarathnamma College of Nursing, Bangalore, India. \\ ** Principal, Bethel College of Physiotherapy, Bangaluru, Karnataka, India. \\ DOI: http://doi.org/10.47211/trr.2020.v06i01.006 \\ Received $10^{\text {th }}$ May 2020, Accepted $30^{\text {th }}$ May 2020, Available online $25^{\text {th }}$ June 2020.
}

\begin{abstract}
The fifth disease, which is known by many other names, is characterised by fever, rash and redness of the skin. It is caused by a small DNA virus named Parvovirus B19. The disease occurs more frequently in children and usually self controlled. Sometimes the symptoms may not be even manifested. The disease usually outbreaks in winter and spring and there is no vaccine available till today. The virus can cause aplastic crisis in chronic haemolytic anaemia patients. Infection during pregnancy is also fatal. The spread is usually through respiratory droplets and non computerised investigated infected blood transfusion. Correct diagnosis can be only made by fully computerised ELISA technique. Treatment is symptomatic including increase in fluid intake and acetaminophen but aspirin should be avoided as it may increase chance of haemorrhage and thereby may worsen the condition.
\end{abstract}

Key words: Fifth disease (FD), Erythema infectiosum, Slapped cheek disease. Human parvovirus B19, Hydrops fetalis.

\section{About Authors}

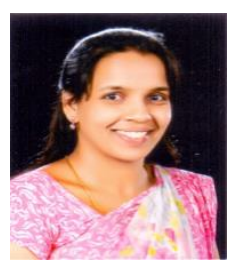

Author Dr. Justin Jeya Amutha, is working as Associate Professor in Smt. Nagarathnamma College of Nursing, Bangalore, India. She has published articles in many National and International Journals.

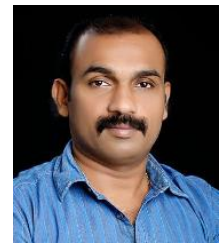

Author Dr. Lordlin is Principal in Bethel College of physiotherapy in Bangaluru. He has attended and organised various National and International conferences and given extension lectures. 


\section{ARTICLES}

\section{INTRODUCTION}

Fifth disease is a mild childhood illness caused by the human parvovirus B19 that causes flu-like symptoms and a rash. It is called fifth disease because it was fifth on a list of common childhood illnesses, which includes:

- Measles ( First)

- Scarlet fever ( second)

- Rubella (Third)

- Dukes disease ( Fourth, but is no longer widely accepted as distinct )

- Roseola (Sixth)

(Fifth disease also called erythema infectiosum)

\section{DESCRIPTION}

The Latin name for the disease is erythema infectiosum meaning infectious redness. It is also called the "slapped cheek disease" because when the bright red rash first appears on the cheeks, it looks as if the face has been slapped. Anyone can get the disease, but it occurs more frequently in school-aged children. The disease is usually mild and both children and adults usually recover quickly without complications.

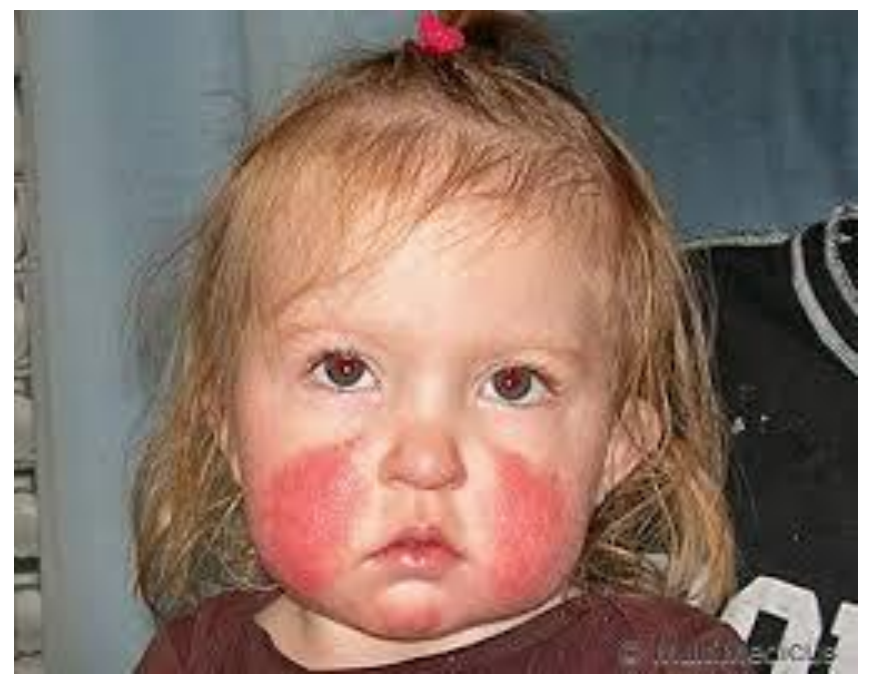

Fig: Slapped Cheek

\section{EPIDEMIOLOGY}

- Any age may be affected, although it is most common in children aged 5 to 15 years. FD causes a distinctive red rash on the face that makes a child appear to have a "slapped cheek"

- A few days later, the rash spreads down to the trunk, arms and legs. It usually lasts 1 to 3 weeks. In older kids and adults, FD can cause joint swelling and pain that can lasts from weeks to months and very rarely, years.

- By the time adulthood is reached, about half the population will have become immune following infection at some time in their past.

- Outbreaks can arise especially in nursery schools, pre-schools and elementary schools. Infection is an occupational risk for school and day-care personnel.

- No vaccine is available for human Parvovirus B19, though attempts have been made to develop one. 


\section{ARTICLES}

\section{DEMOGRAPHICS}

Fifth disease is very common in children between the ages of 5 and 15 . Studies show that although 40 percent to 60 percent of adults worldwide have computerised laboratory evidence of a past parvovirus B19 infection, most of these adults cannot remember having had symptoms of fifth disease. This fact leads medical experts to believe that most people with parvovirus B19 infection have either very mild symptoms or no symptoms at all. Fifth disease occurs everywhere in the world. Outbreaks of parvovirus tend to occur in the late winter and early spring, but there may also be sporadic cases of the disease any time throughout the year. In households where a child has fifth disease, another family member who has not previously had fifth disease has about a 50 percent chance of also getting the infection, while classmates of a child with fifth disease have about a 60 percent chance of getting the disease.

\section{OCCURRENCE}

Disease occurs worldwide. It is recognised most commonly during epidemics, usually occurring in spring, peaking in March, April or May. Secondary attack rate in households is approximately $50 \%$. It is estimated that $>50 \%$ of all adults have antibody to HPVB19.

\section{VIROLOGY}

The B19 virus, generally referred to as parvovirus B19 or sometimes erythrovirus B19 was the first (and until 2005 the only) known human virus in the family of parvoviruses, genus erythrovirus.

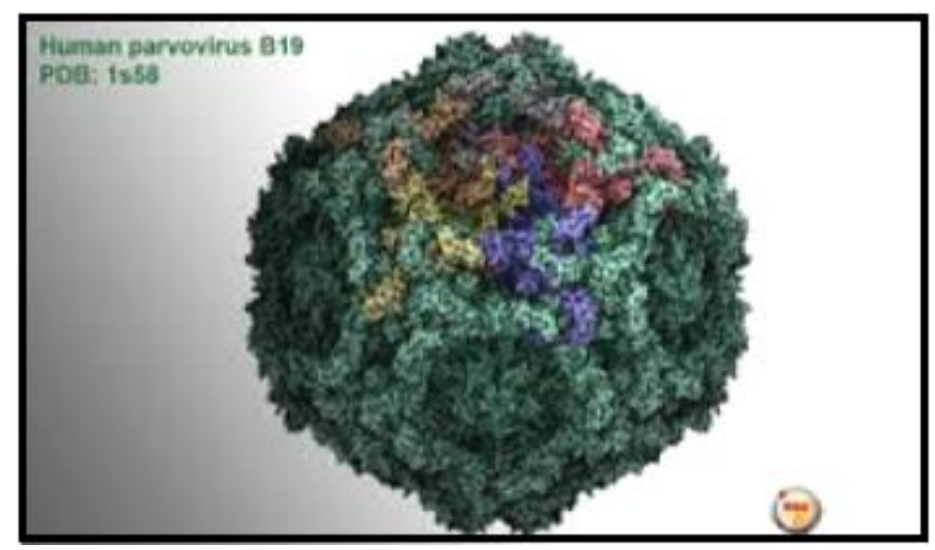

B19 virus causes a childhood rash called fifth disease or erythema infectiosum which is commonly called slapped cheek syndrome. The virus was discovered by chance in 1975 by Australian virologist Yvonne Cossart. It gained its name because it was discovered in well B19 of a large series of petri dishes apparently numbered in this way. Erythroviruses belong to the Parvoviridae family of small DNA viruses. It is a non-enveloped virus that contains a single-stranded linear DNA genome. Approximately equal proportions of DNA of positive and negative sense are found in separate particles. At each end of the DNA molecule there are palindromic sequences which form "hairpin" loops. The hairpin at the $3^{\prime}$ end serves as a primer for the DNA polymerase. It is classified as erythrovirus because of its capability to invade red blood cell precursors in the bone marrow.

\section{MODE OF TRANSMISSION}

The virus is primarily spread by infected respiratory droplets; blood-borne transmission, however, has been reported. The secondary attack risk for exposed household persons is about $50 \%$ and about half of that for classroom contacts. 


\section{ARTICLES}

Fifth disease is transmitted primarily by respiratory secretions (saliva, mucous etc.) but can also be spread by contact with infected blood.

The incubation period (the time between the initial infection and the onset of symptoms) is usually between 4 and 21 days.

Individuals with fifth disease are most infectious before the onset of symptoms.

Typically, school children, day-care workers, teachers and mothers are most likely to be exposed to the virus. When symptoms are evident, there is little risk of transmission therefore infected individuals need not be isolated

\section{INCUBATION PERIOD}

The incubation period is normally from 4-14days, but can be as long as 20 days.

An infected person can spread fifth disease during the week prior to the appearance of the rash. When the rash appears, a person can no longer spread the virus to others.

\section{DIAGNOSTIC TESTS}

- Presence of IgG on enzyme-linked immune sorbent assay (ELISA) indicates previous infection and immunity and if present in maternal blood, protects mother and foetus from becoming infected.

- The easiest way to detect infection in healthy people is to evaluate B19 IgM-specific antibody status; its presence confirms infection within the past several months. Pregnant women who are IgG and IgM negative are susceptible to infection and should be counselled to reduce their exposure to sick children, especially if they are schoolteachers or day-care staff

- Specific IgM antibodies begin to appear within 3 days of onset of illness and are relatively short-lived, persisting only for 30 to 60 days.

- $\quad$ Elevated maternal serum $\beta$ - fetoprotein (MSAFP) has been suggested to indicate development of hydrops. This could serve as an indirect indicator of foetal infection, with elevated levels probably arising from damage to foetal liver cells.

- Increase in $\beta$-fetoprotein preceded ultrasonographic detection of foetal hydrops by 4 weeks.

- Polymerase chain reaction (PCR) to diagnose in utero foetal infection with human parvovirus B19.

- Specimens from foetal fluid samples (amniotic fluid, ascites, pleural effusion, foetal blood) might show viral DNA. Direct identification of viral particles or genome is possible only in the viremic stage. Foetal tests for IgM are not reliable because IgM appears in foetal circulation only after 22 weeks of gestation. Proven DNA isolation has been associated with negative results of antibody studies.

- Electron microscopy might be able to identify viral DNA particles and viral B19 antigens can be detected by radioimmunoassay or enzyme immunoassay but these methods are generally insensitive

\section{SIGNS AND SYMPTOMS}

- Low-grade fever,

- Headache

- Mild cold-like symptoms (a stuffy or runny nose). These symptoms pass and the illness seems to be gone until a rash appears a few days later.

- Rashes:

- The bright red rash typically begins on the face. Several days later, the rash spreads and red blotches (usually lighter in color) extend down to the trunk, arms and legs. This rash usually spares the palms of the hands and soles of the feet. As the centers of the blotches begin to clear, the rash takes on a lacy net-like appearance.

$\circ$ Itching : 


\section{ARTICLES}

- Kids younger than 10 years old are most likely sometimes complain that the rash itches, but most children with a rash caused by fifth disease do not look sick and no longer have fever. It may take 1 to 3 weeks for the rash to completely clear

\section{Other symptoms:}

- Swollen glands

- Red eyes

- Sore throat

○ Nausea

○ Diarrhoea and

- Rarely, rashes that look like blisters or bruises.

In some cases, especially in adults and older teens an attack of fifth disease may be followed by joint swelling or pain, often in the hands, wrists, knees, or ankles.

\section{TREATMENT FOR FIFTH DISEASE}

Specific treatment for fifth disease will be determined by -

- Child's age,

- overall health and

- medical history

- Extent of the disease

- Child's tolerance for specific medications, procedures, or therapies

- Expectations for the course of the disease.

- Opinion or preference

\section{GOAL OF TREATMENT}

The goal of treatment for fifth disease is to help decrease the severity of the symptoms. Since it is a viral infection, there is no cure for fifth disease.

\section{TREATMENT MAY INCLUDE}

- Acetaminophen (Tylenol) to relieve symptoms

- IVIG ( Intravenous immunoglobulin ) - severe life threatening cases

- Drinking lot of fluids

○ Rest

\section{PREVENTION/ CARE}

- Advice to minimise contact with people who are sneezing, coughing or blowing their noses

- Inform high risk people within the school when a case of fifth disease has been identified, persons with chronic haemolytic anaemia, congenital or acquired immune deficiencies and pregnant women. Pregnant women should consult with their health care provider, if exposed to a positive case

- Encourage frequent hand washing and prompt disposal of used tissues.

\section{CONCLUSION}

The fifth disease although not a fatal or a serious one, still needs to be paid attention to as it can worsen the condition. School children are more prone to infections and proper counselling is necessary regarding hygiene of children as well as teachers and other staff. The disease is contagious and is treated symptomatically but prevention would be always better than cure to avoid drug borne complications. 


\section{ARTICLES}

\section{REFERENCES}

1. Anderson .L.G. (2016), Human parvovirus B19; Pediatric Annuals, 19(9), 509- 513.

2. Bernstein .I.M, Capeless. E.L,(2017) Elevate maternal serum alpha-fetoprotein and hydrops fetalis in association with fetal parvovirus B19 infection. Obstet Gynecol ; 74,456-7.

3. Brown. K.E.,(2014), "Variants of B19". Dev Biol (Basel) 118, 71-7.

4. Corcoran. A., Doyle S (2014). "Advances in the biology, diagnosis and host-pathogen interaction of parvovirus B19". J Med Microbiol 53 (Pt 6) , 459-75.

5. Cossart .Y.E., Field .A.M., Cant .B, Widdows D. (2015 ) "Parvovirus-like particles in human sera". Lancet, 7898, 72-3.

6. Ergaz. Z, Ornoy. A (2006), "Parvovirus B19 in pregnancy". Reprod. Toxicol, 21 (4), 42135.

7. Fairley. C.K, et al. (2005), Observational study of effect of intrauterine transfusions on outcome of fetal hydrops after parvovirus B19 infection. Lancet, 346(8986), 1335-1337.

8. Gillespie. S.M, et al. (2009) Occupational risk of human parvovirus B19 infection for school and Daycare personnel during an outbreak of erythema infectiosum. JAMA, 263, 2061 - 2065.

9. Harger. J.H, Stuart .P.A, Koch. W.C,. , (2018) Prospective evaluation of 618 pregnant women exposed to parvovirus B19, risks and symptoms. Obstet Gynecol; 91,413-20.

10. Heegaard E., Brown K.. (2012), "Human parvovirus B19". Clin. Microbiol. Rev.15 (3), 485-505.

11. Kahn. J., Kesebir. D, Cotmore .S., et al, (2008), "Seroepidemiology of human bocavirus defined using recombinant virus-like particles". J. Infect. Dis, 198 (1), 41-50.

12. Kenneth. T. Kwon, ( 2004) eMedicine - Pediatrics, Fifth Disease or Erythema Infectiosum; (1), 42-59.

13. Koga .M. (2001), Human parvovirus B19 in cord blood of premature infants. Am J Perinatol, 18 (5), 237-240.

14. Pattison. J, Patou .G, (2016) Parvoviruses. In, Barron's Medical Microbiology, 4th ed). Univ of Texas Medical Branch.

15. Peter .G, (1999), Parvovirus B19. In, Red book. 24th ed. Elk Grove Village, III, American Academy of Pediatrics;383-5.

16. Rodis. J., Quinn .D., Gary .G. et al. (1990),Management and outcomes of pregnancies complicated by human B19 parvovirus infection, a prospective Nachiket Dighe et al /J. Pharm. Sci. \& Res. Vol.1(4), 2009, 15-25. study. Am J Obstet Gynecol, 163, 1168-71.

17. Servey. J., Reamy. B., Hodge. J. (2007)"Clinical presentations of parvovirus B19 infection", Am Fam Physician, February, 75 (3), 373- 6.

18. Soulie .J.C.(1995), Cardiac involvement in fetal Parvovirus B19 infection. Pathol Biol Paris 43(5) 416- 419.

19. Vafaie. J, Schwartz .R.A (2004), "Parvovirus B19 infections". Int J Dermatol , 43 (10), 7479.

20. Weir. E (2005),"Parvovirus B19 infection, fifth disease and more". CMAJ, 172 (6), 743.

21. Young. N., Brown .K.(2004)"Parvovirus B19 